\title{
Presiden Wanita dalam Perspektif Media
}

\author{
Aning Sofyan Sadikin
}

\begin{abstract}
This controversy looks like never ending: Did Islam permitt a woman to become a president? Before SI 2001, the polemic of that problem still happened, even more strict. It is not strange if mass media gave bigger covering on that issue. This research tries to describe news covering on two ideological different national newspapers, Republika and Kompas, periode June until July 2001.
\end{abstract}

Kata kunci: presiden wanita, republika, kompas

\section{Pendahuluan}

Dikeluarkannya memorandum II yang berlanjut dengan digelarnya Sidang Istimewa (SI) MPR RI untuk meminta pertanggungjawaban Presiden KH. Abdurrahman Wahid merupakan suatu peristiwa atau event yang menjadi sumber daya (resources) bagi isi berita media massa, antara bulan Mei sampai menjelang 01Agustus 2001. Akan tetapi, karena sesuatu hal, SI diselenggarakan pada 21 Juli 2001.

Menarik untuk dicermati dalam kurun waktu tersebut, pemberitaan tentang Wapres Megawati Soekarnoputri menjadi Presiden RI, menyusul ditolaknya pertanggungjawaban Presiden KH. Abdurrahman Wahid pada SI MPR RI. Hal ini sudah terlaksana, mengingat sikap Wapres Megawati dan juga sikap partainya (PDIP) yang sudah tidak mau kompromi lagi dengan presiden. Inisiatif Gus Dur gagal mengadakan pertemuan pimpinan parpol di Istana Bogor, 9 Juli 2001, hanya dihadiri oleh Ketua PKB, Matori Abdul Jalil, antara lain, disebabkan oleh pernyataan wapres yang juga Ketua Umum DPP PDIP, Megawati Soekarnoputri, di sela acara
Lemhanas, sebagaimana dikutip Republika (10 Juli 2001) bahwa "kita sudah pilih orang" untuk menjadi presiden.

Sebenarnya, kesiapan Megawati menjadi Presiden RI, bukanlah kali ini saja. Tetapi, juga sudah mengemuka sejak Kongres PDIP yang mengantarkan Megawati kembali menjadi Ketua Umum PDIP dan mengamanatkan bahwa calon Presiden RI dari PDIP pasca Pemilu 1999 adalah Megawati Soekarnoputri. Ini dibuktikan dengan walk out-nya perjuangan F-PDIP pada Sidang Umum MPR RI tahun 2000. Sebagai peraih suara terbanyak Pemilu 1999, dengan kursi yang paling banyak di parlemen, sebetulnya F-PDIP berpeluang besar menjadikan Megawati Soekarnoputri menjadi Presiden RI, ketika itu. Tetapi, akibat skenario kelompok poros tengah, yang kurang menghendaki Megawati Soekarnoputri menjadi Presiden RI, dengan alasan wanita menjadi Presiden masih menjadi perdebatan di antara para ulama, terlebih di negara kita, maka jadilah, ketika itu, KH. Abdurahman Wahid menjadi Presiden RI yang keempat.

Hal-hal yang dikemukakan tersebut, tidak 
lepas dari peran media massa (surat kabar) dalam memuat isi berita tentang peristiwa-peristiwa yang sudah disebutkan di muka. Ini berarti bahwa media massa (surat kabar) memegang peranan penting dalam kehidupan berbangsa dan bernegara di manapun mereka berada.

Runtuhnya rezim Orde Baru dan munculnya sosok Megawati, telah menumbuhkan kepercayaan di kalangan masyarakat Indonesia bahwa Mega layak tampil sebagai presiden. Selain itu, Mega yang sering di cap mewarisi kharisma bapaknya, Proklamator RI, Ir. Soekarno, yang kemudian menjadi salah satu pemimpin partai politik(PDIP) dan membawa PDIP sebagai pemenang pada Pemilu 1999. Selain berita kemenangan partainya, sejarah tampilnya megawati ke pentas politikpun, tidak luput mendapat perhatian serius dari media. Hadirnya putri sulung Bung Karno ke pentas politik yang bermula dari perlawanannya menghadapi tirani Orde Baru yang secara logika sulit ditumbangkan, merupakan nilai plus yang meraih simpati rakyat, seperti kasus 27 Juli 1996.

Polemik tentang presiden wanita (pro-kontra presiden wanita), menjadikan media massa sebagai ajang perebutan pengaruh, sekaligus juga komoditas politik dalam menyikapi kemungkinan Megawati menjadi presiden wanita pertama di negeri ini. Perlombaan pembentukan opini tentang sah tidaknya wanita menjadi pemimpin negara dalam pandangan Islam yang dilakukan oleh beberapa media massa, mengakibatkan langkah Mega, pasca Pemilu 1999, sesaat tertahan menjadi Presiden, meskipun PDIP sebagai pemenang Pemilu 1999. Tetapi, setelah dikeluarkannya memorandum II yang berlanjut pada rekomendasi Sidang Istimewa MPR RI, peluang Megawati untuk naik menjadi Presiden RI terbuka kembali, walaupun masih ada yang mempersoalkan sah atau tidaknya wanita menjadi Presiden di sebuah negara dengan mayoritas rakyatnya beragama Islam.

Pandangan terhadap presiden wanita, banyak dilakukan oleh kalangan umat beragama, khususnya agama Islam. Hal ini mengingat masih terdapatnya perbedaan yang cukup tajam terhadap fiqih tentang kemungkinan wanita menjadi pemimpin negara. Dalam sudut pandang syariah, tafsiran Al-Quran Surah An-Nisaa: 34, yang berbunyi:

"Kaum laki-laki itu adalah pemimpin bagi kaum wanita, karena Allah telah melebihkan sebagian dari mereka (laki-laki) atas sebagian yang lain, dan karena mereka (laki-laki) telah menafkah sebagian dari harta mereka. Sebab itu, maka wanita yang saleh, ialah yang taat kepada Allah lagi memelihara diri ketika suaminya tidak ada, oleh karena Allah telah memelihara (mereka) wanita yang kamu kuatirkan nusuz-nya, maka nasihatilah mereka dan pisahkanlah mereka di tempat tidur mereka, dan pukullah mereka. Kemudian, jika mereka menaatimu, maka janganlah mencari-cari jalan untuk menyusahkannya. Sesungguhnya Allah Maha Tinggi lagi Maha Besar.”

Kandungan ayat di atas, menerangkan bahwa keberadaan laki-laki atas perempuan adalah pemimpin. Ayat di atas merupakan suatu dalil terhadap penolakan kepemimpinan wanita. Selain itu, secara tegas Persatuan Islam (Persis), sebagai organisasi kemasyarakatan Islam, mengeluarkan fatwa tentang hukum wanita menjadi seorang pemimpin, yang secara tegas menyatakan penolakannya. Di lain pihak, NU terbagi dua, yaitu ada yang menolak dan mendukung kepemimpinan wanita.

Dalam Hadis Nabi Muhammad Saw yang diriwayatkan Imam Bukhari, menegaskan, "Tidak akan sukses suatu kaum yang mengangkat seorang wanita sebagai pemimpin".

Dari hadis tersebut di atas, sangat tegas dan jelas bahwa kalau wanita diangkat menjadi pemimpin, tunggulah saat kehancuran kaum tersebut. Di sisi lain, pandangan yang mengatakan tidak ada larangan bagi wanita untuk memimpin negara, juga merujuk kepada dalil bahwa laki-laki dan wanita adalah makhluk Tuhan yang mempunyai kedudukan dan hak yang sama, sehingga tidak masalah apabila kaum perempuan turut berperan dalam perpolitikan dan pemerintahan baik eksekutif maupun legislatif.

Perbedaan pandangan tersebut dijadikan wacana dalam proses demokratisasi di Indonesia saat ini. Perbedaan-perbedaan ini sesuatu yang biasa dalam iklim berdemokrasi. Dengan perbedaan 
ini, kalangan politisi ternyata tidak tinggal diam. Mereka berupaya merekayasa sedemikian rupa, sehingga hal tersebut dijadikan komoditas politik yang mengarah kepada kemenangan politik tertentu.

K.H. Ilyas Ruchiat dalam wawancara dengan Majalah Forum, bertajuk "Ulama yang Menolak Lebih Banyak”, walaupun terkesan malu-malu, pada hakikatnya wanita tidak bisa jadi pemimpin. Ini ditunjukkan jumlah besaran yang mendukung lebih kecil dan jumlah yang menolak lebih besar.

Kontroversi mengenai presiden wanita tersebut menjadi suatu isu publik, membesar ataupun mengecil, akan sangat tergantung pada agenda dari tiap-tiap institusi media massa itu sendiri. Hal ini tidak terlepas dari adanya gejala pemihakan dari suatu media massa terhadap organisasi politik. Penelitian yang dilakukan Hamdan (1995) mengisyaratkan terdapat gejala pemihakan dari surat kabar terhadap organisasi politik tertentu baik pada aspek berita maupun opininya.

Keberadaan surat kabar juga tidak luput dari pendekatan misi dan visi, dan yang sering kali dijadikan subjek visi dan misi itu sendiri adalah hal-hal yang berkaitan dengan agama, ideologi, dan politik. Keberadaan surat kabar yang seharusnya netral, sering disalahtafsirkan oleh orang-orang yang mempunyai kepentingan tertentu, terutama dalam dimensi kekuasaan. Keberpihakan pada kelompok kepentingan tertentu dalam membidik pembaca, merupakan sasaran strategis dalam komunikasi poltik. Tetapi secara ideal, keberadaan surat kabar seharusnya berlaku objektif dan hal inilah yang menyebabkan tinggirendahnya tingkat kepercayaan masyarakat informasi terhadap keberadaan surat kabar sampai sekarang.

Keberadaan pers di suatu negara biasanya mengikuti sistem politik yang berlaku secara konstitusional. Kehadiran pers di Indonesia harus mengacu pada UU yang berlaku, yaitu UUD 1945. Kenyataan politik pada dekade tahun 2000-an, menunjukkan bahwa kebebasan pers telah masuk ke wilayah liberalisme atau sebuah kebebasan dengan menggunakan tafsir demokrasi.
Pemberitaan surat kabar pada dekade ini, bagaikan kuda lepas dari kandangnya; meloncatloncat berlari tanpa arah dan mendengus-dengus kemana saja (Kompas, 9 Februari 1999) dalam Alex Sobur (2001:viii). Bingkai demokratisasi yang lepas dari peraturan yang berlaku ini, tercermin dari bebasnya orang berpendapat yang cenderung mengabaikan koridor tata budaya yang berlaku.

Kontroversi tentang presiden wanita menjadi pemimpin negara pada masyarakat yang mayoritas Islam, merupakan suguhan media massa, sekaligus kebutuhan masyarakat yang haus akan kebenaran.

Pemilihan surat kabar Republika dan Kompas dalam penelitian ini berdasarkan pandangan bahwa Republika sebagai media representasi umat Islam dengan membawa misi dan visi dakwah (berdasarkan sejarah lahirnya berasal dari ICMI). Sedangkan Kompas adalah media representasi kaum nasionalis yang membawa misi, visi, dan kepentingan nasional serta bisnis, sehingga tidak mempermasalahkan kepemimpinan wanita.

Berdasarkan latar belakang masalah tersebut, rumusan masalah yang diajukan adalah "Sejauhmana media massa memberikan persepsi terhadap presiden wanita di Indonesia”. Untuk mengkaji lebih mendalam, fokus penelitiannya adalah mencari perbedaan yang signifikan surat kabar nasional, yaitu surat kabar Republika dan Kompas dalam mengangkat isu persiden wanita di tengah kontroversi sah-tidaknya wanita menjadi pemimpin negara dalam konsepsi Islam. Identifikasi masalah meliputi: frekuensi, volume, aspek berita, aspek tajuk rencana, dan aspek artikel atau opini.

Berita surat kabar yang berkaitan dengan polemik atau pro-kontra presiden wanita di Indonesia menjadi objek yang menarik untuk diteliti. Dengan demikian, tujuan penelitian ini adalah untuk mengetahui, memahami, dan menjelaskan netralitas atau objektivitas surat kabar terhadap presiden wanita di Indonesia, yang tercermin pada surat kabar Republika dan Kompas.

\section{Kedudukan Media Massa dalam Pendekatan Teori}

Keberadaan organisasi tidak terlepas dari pendekatan structural-fungsional, yaitu: (1) adakah 
sesuatu itu berfungsi; (2) bagaimana sesuatu itu berfungsi; dan (3) mengapa sesuatu itu berfungsi (Garna, 1993:55). Lebih jauh, Garna mengungkapkan bahwa hakikat keberadaan organisasi adalah berfungsinya seluruh unsur dan terjembataninya kebutuhan dan tuntutan anggota organisasi tersebut dan masyarakat di mana organisasi itu berada. Kaidah atau aturan dalam masyarakat adalah berkaitan tentang hubungan antara individu, individu dengan instansi sosial, dan hubungan antara institusi sosial dengan institusi sosial lainnya, sehingga sesuatu masyarakat ialah sistem berkaitan dan memiliki pola kepentingan pada masyarakat.

Paradigma yang dikaji dalam tulisan ini berkaitan dengan kedudukan dan fungsi media massa, sehingga pendekatan Fungsionalism Theory (Aguste Comte,1789-1837) dan Structural Funksionalism Theory (Parson, 1937) dijadikan sebagai "Grand Theory". Selanjutnya, sebagai "Middle Range Theory" digunakan operasionalisasi fungsi dan tujuan media massa (Mc Quail: 1987). Sedangkan “Applied Theorynya” adalah Agenda Setting Model (Cohen, 1963).

\section{Dampak Terpaan Media Massa}

Terpaan media dapat menimbulkan efek terhadap khalayak, baik dari segi kognitif, afektif, maupun konatif. Hanya saja, seberapa besar dampak tersebut pada khalayak, masih menjadi perdebatan di kalangan ahli komunikasi. Pendukung Teori Peluru, misalnya, sangat mempercayai kekuatan media dalam memengaruhi tanpa memperhitungkan aspek kemanusiaan khalayak yang memiliki kemampuan untuk memilih. Sementara, di lain pihak, teori Uses and Gratification justru mengecilkan kekuatan media dan membesarkan persepsi selektif khalayak yang secara aktif menyeleksi pesan sesuai kebutuhannya. Tetapi, terlepas dari pokok perdebatan di atas, persoalan atau perdebatan tersebut lahir karena di tataran praktis menunjukkan ada rentang efek suatu terpaan tertentu dengan terpaan yang lain, karena ada faktor-faktor khas dalam komponen komunikasi yang memengaruhi arus pesan.

\section{Kedudukan Wanita dalam Perspektif Islam}

Islam memandang wanita dari sudut pandang keimanan sebagai individu anggota umat yang dikaitkan dengan individu lain dengan ikatan kaidah. Wanita pada hakikatnya adalah sesosok makhluk yang memiliki peran dalam perkembangan umat, khususnya dalam pendidikan di tingkat keluarga, karena pendidikan yang didapatkan anak manusia pertama kali adalah melalui sentuhan tangan wanita.

Keberadaan perempuan atas laki-laki dalam keluarga, sebagai bentuk miniatur pemerintahan terkecil, dapat dijadikan referensi dalam melihat posisi serta tabiat dan perilaku wanita yang sholehah. Dalam sudut pandang syariah, tafsiran Al-Quran surah An-Nisa: 34, telah jelas menerangkan bahwa keberadaan laki-laki atas perempuan adalah pemimpin. Hal tersebut merupakan suatu dalil terhadap penolakan kepemimpinan wanita.

Tanggung jawab wanita sebagai seorang pemimpin, lebih kental dengan keluarga sebagai bagian terkecil dari kaum, dia memiliki tugas mendidik anak dan menjaga harta suaminya, urusan keluarga menjadi bagian terpenting dari peran wanita dalam usaha mewujudkan hak manusia yang mengedepankan kesamaan gender.

Apabila kita merujuk pada hadis Rasulullah, "Wahai kaum wanita, bersedekahlah, karena sesungguhnya saya melihat kebanyakan kalian menjadi penduduk neraka. Mereka berkata: 'Mengapa wahai Rasulullah?' Beliau menjawab: 'Kalian banyak melakukan laknat dan meninggalkan keluarga. saya tidak melihat orang yang kurang akal dan agamanya yang melebihi orang yang meningglakan suaminya daripada kamu sekalian.' Mereka berkata: Apakah kekeurangan agama dan akal kami wahai Rasulullah?' Rasulullah Saw. menjawab: 'Bukankah kesaksian wanita sama dengan setengah kesaksian lelaki?' Mereka berkata: 'Ya, 'Rasulullah Saw bersabda, 'Itulah kekurangan akalnya. Bukankah apabila wanita sedang haid dia tidak salat dan tidak berpuasa?' Mereka menjawab: 'Ya.' Rasulullah Saw besabda: 
'Itulah kekurangan agamanya.'

Kemudian, sebagian ulama berbicara mengenai tabiat wanita yang kurang dan bengkok moralitasnya, serta cenderung untuk mengikuti hawa nafsu. Mereka menganggap bahwa kekurangan itu merupakan sifat yang berkaitan dengan kodratnya sebagai wanita. Yang berarti penggunaan rasio dan akal yang tidak seimbang dengan hawa nafsu yang dapat menimbulkan kurang objektifnya wanita dalam memandang suatu permasalahan, ini dapat menimbulkan kecenderungan terjadinya perpecahan yang pada akhirnya berarti wanita lebih mengedepankan perasaan sesuai dengan kodratnya.

Adapun polemik tentang kepemimpinan wanita, dalam Hadis Nabi Muhammad Saw yang diriwayatkan Imam Bukhari, yang artinya: “Tidak akan sukses suatu kaum yang mengangkat seorang wanita sebagai pemimpin". Dari hadis tersebut sangat tegas dan jelas bahwa kalau wanita diangkat menjadi pemimpin, tunggulah saat kehancurannya kaum tersebut.

Sedangkan bagi kalangan yang menganggap tidak ada larangan bagi wanita untuk menjadi seorang pemimpin, juga merujuk kepada dalil bahwa laki-laki dan wanita adalah makhluk Tuhan yang mempunyai kedudukan dan hak yang sama dengan kaum laki-laki, sehingga tidak masalah apabila kaum perempuan turut berperan dalam perpolitikan dan pemerintahan, baik eksekutif maupun legislatif.

\section{Analisis Data Hasil Penelitian}

Sebelum pembahasan hasil penelitian, akan terlebih dahulu disajikan uji hipotesis.

Uji hipotesis ini menggunakan rumus chisquare:

$$
x^{2}=\sum_{i=1}^{K} \frac{(\mathrm{Oi}-\mathrm{Ei})^{2}}{\mathrm{El}}
$$

Dengan taraf nyata $=0,05$ dan derajat kebebasan (dk) untuk distribusi chi-kuadrat $=(B-$ 1) (K-1). Hasil hipotesisnya, sebagai berikut:

Hipotesis 1 tentang frekuensi pemberitaan. Dari uji hipotesis menunjukkan bahwa Ho diterima dengan taraf nyata $=0,05$ dan derajat kebebasan $\mathrm{dk}=2$. Dimana perhitungannya jika $\mathrm{X} 2$ hitung $<$ dari X2 tabel maka Ho diterima dan H1 ditolak. Dari perhitungan didapat X2 hitung $=5,101$ dan X2 tabel $=5,99$. Maka kesimpulannya, Ho diterima untuk kategori frekuensi pemberitaan dan H1 ditolak untuk frekuensi pemberitaan, yaitu tidak ada perbedaan frekuensi di antara kedua surat kabar dalam hal pemuatan berita, artikel, dan tajuk rencana dalam kategori frekuensi.

Hipotesis 2 tentang volume pemberitaan. Dari uji hipotesis menunjukkan bahwa Ho ditolak dengan taraf nyata $=0,05$ dan derajat kebebasan $\mathrm{dk}=2$. Di mana perhitungannya, jika X2 hitung $>$ dari X2 tabel maka Ho ditolak dan H1 diterima. Dari perhitungan didapat X2 hitung $=270,86$ dan X2 tabel $=5,99$. Maka kesimpulannya, Ho ditolak untuk kategori frekuensi pemberitaab dan $\mathrm{H} 1$ diterima untuk volume pemberitaan, yaitu ada perbedaan dalam volume di antara kedua surat kabar dalam hal pemuatan berita, artikel, dan tajuk rencana dalam kategori volume.

Hipotesis 3 tentang penempatan berita. Dari uji hipotesis menunjukkan bahwa Ho diterima dengan taraf nyata $=0,05$ dan derajat kebebasan $\mathrm{dk}=2$. Di mana perhitungannya, jika X2 hitung > dari X2 tabel maka Ho diterima dan H1 ditolak. Dari perhitungan didapat $\mathrm{X} 2$ hitung $=5,777$ dan $\mathrm{X} 2$ tabel $=5,99$. Maka kesimpulannya, Ho diterima untuk kategori penempatan berita dan $\mathrm{H} 1$ ditolak untuk penempatan berita, yaitu tidak ada perbedaan penempatan di antara kedua surat kabar dalam hal berita.

Hipotesis 4 tentang kecenderungan berita. Dari uji hipotesis menunjukkan bahwa Ho diterima dengan taraf nyata $=0,05$ dan derajat kebebasan $\mathrm{dk}=2$. Di mana perhitungannya jika X2 hitung $>$ dari X2 tabel maka Ho ditolak dan H1 diterima. Dari perhitungan didapat X2 hitung $=22,63$ dan X2 tabel $=5,99$. Maka kesimpulannya, Ho ditolak untuk kategori kecenderungan berita dan $\mathrm{H} 1$ diterima untuk kecenderungan berita, yaitu ada perbedaan kecenderungan di antara kedua surat kabar dalam hal berita.

Hipotesis 5 tentang kecenderungan tajuk rencana. Dari uji hipotesis menunjukkan bahwa Ho 
diterima dengan taraf nyata $=0,05$ dan derajat kebebasan $\mathrm{dk}=2$. Di mana perhitungannya jika X2 hitung $<$ dari X2 tabel maka Ho diterima dan H1 ditolak. Dari perhitungan didapat X2 hitung = 2,64 dan X2 tabel $=5,99$. Maka kesimpulannya, Ho diterima untuk kategori kecenderungan tajuk rencana dan $\mathrm{H} 1$ ditolak untuk kecenderungan tajuk rencana, yaitu tidak ada perbedaan kecenderungan tajuk rencana di antara kedua surat kabar.

Hipotesis 6 tentang kecenderungan artikel. Dari uji hipotesis menunjukkan bahwa Ho ditolak dengan taraf nyata $=0,05$ dan derajat kebebasan $\mathrm{dk}=2$. Di mana perhitungannya jika X2 hitung $>$ dari X2 tabel maka Ho ditolak dan H1 diterima. Dari perhitungan didapat X2 hitung $=22,63$ dan X2 tabel $=5,99$. Maka kesimpulannya Ho ditolak untuk kategori kecenderungan artikel dan $\mathrm{H} 1$ diterima untuk kecenderungan artikel, yaitu ada perbedaan kecenderungan artikel di antara kedua surat kabar.

\section{Analisis Kualitatif}

Hamka dalam Tafsir Al-Azhar, Juz V (1983 : 59), laki-laki jadi pemimpin atas perempuan adalah soal 'kenyataan', hal ini dijelaskan :

"Siapa yang menghadapi, ketika di dalam rumah seorang istri sedang menggugat masalah kepemimpinan suaminya, lalu datang orang jahat yang akan merampok rumah itu. Dengan tidak ada perintah terlebih dahulu yang bersiap menghadapi musuh itu ialah laki-laki (suami), dan yang disuruh oleh laki-laki bersembunyi ialah perempuan (istri) dan anak-anaknya. Dan kalau pun sudah ada anak laki-laki yang besar-besar, mereka diperintah oleh bapaknya, untuk bersama-sama menghadapi musuh. Itu karena, laki-laki lebih kuat tenaganya, lebih cerdas pemikirannya, dan lebih tenang dalam menghadapi situasi. Laki-laki lebih mengedepankan pikiran."

Lain lagi yang termaktub dalam hadis Nabi Muhammad Saw yang diriwayatkan oleh Iman Bukhari, yang artinya: "Tidak akan sukses suatu kaum yang mengangkat seorang wanita sebagai pemimpin". Dari hadis tersebut sangat tegas dan jelas bahwa kalau wanita diangkat menjadi pemimpin, tunggulah saat kehancurannya kaum tersebut. Jika suatu negara memaksakan mengangkat seorang wanita, niscaya negara tersebut tinggal menunggu kehancuran.

Lebih tegas lagi Hamka (1983: 59) menjelaskan posisi laki-laki sebagai pemimpin atas perempuan adalah soal kenyataan, "Mau tidak mau, laki-lakilah pemimpin perempuan. Mungkin sekali-sekali kedapatan laki-laki tolol dan perempuan cerdik, sehingga terbalik, perempuan yang memimpin. Yang jarang terjadi adalah seumpama tidak. Tidak ada dalam dunia orang yang menjadikan hal yang jarang terjadi menjadi pokok dan dalil hukum." Mungkin saja di Indonesia hal yang 'jarang' ini (perempuan lebih cerdik) ditemukan, sehingga perempuan diangkat menjadi presiden. Namun, kalau mengacu kepada penafsiran Hamka, peristiwa yang 'jarang' terjadi ini tidak bisa dijadikan alasan pokok atau pun dalil hukum diperbolehkannya perempuan menjadi presiden.

Analisis di atas bukan tidak ada pijakan. Di dalam Islam, sumber pengambilan suatu hukum dari Al-Quran, hadis. Kemudian dijelaskan dalam atsar sahabat, qiyas, ijma, ulama, maslahatul mursalah dan seterusnya.

Islam memang memberi kemungkinan adanya penyesuaian dan keputusan rasional yang dilandasi oleh ijtihad (pertimbangan akal sehat), syura (musyawarah), dan ijma (konsensus/ kesepakatan). Semua itu tergambar dalam percakapan di atas.

Namun, pada zaman kontemporer, berhamburan berbagai sudut pandang lain yang kadang hanya mengandalkan rasionalitas belaka, tanpa sungguh-sungguh menempuh jalur tatacara pengambilan hukum (syar'i) - (lihat: Ahmed: 1992:27) bahwa tidak ada larangan bagi wanita untuk memimpin negara dengan merujuk dari dalil bahwa laki-laki dan wanita adalah makhluk Tuhan yang mempunyai kedudukan dan hak yang sama.

Dengan melihat perbedaan pandangan mengenai wanita, terutama menyangkut masalah kepemimpinan wanita, maka penelitian tentang presiden wanita dari perspektifmedia yang diwakili oleh dua surat kabar nasional, yaitu Republika dan Kompas sebagai written and printed media, memegang peranan penting dalam kehidupan berbangsa dan bernegara di mana pun, karena 
Terakreditasi Dirjen Dikti SK No. 56/DIKTI/Kep/2005

dapat menyampaikan suatu informasi kepada masyarakat luas secara bebas, tanpa campur tangan kekuasaan (negara), yang dituangkan ke dalam bentuk berita, artikel, kolom, ilustrasi, foto, wawancara, dan tajuk rencana (editorial).

Realitas yang terjadi, ternyata media massa tidak lagi berdiri di atas kepentingan masyarakat, oleh karena kepentingan kapitalis dan faktor kepemilikan media oleh konglomerasi, menyebabkan media massa mulai meninggalkan masyarakat sebagai objek informasi. Di sini, yang bermain adalah uang. Dan siapa atau kelompok mana yang bisa membayar dengan nominal uang lebih tinggi, kelompok itulah yang akan diuntungkan, tidak peduli masyarakat meninggalkannya. Dalam buku Sembilan Elemen Jurnalisme (Kovach dan Rosenstiel, 2003:28), ditegaskan, "Kita sedang melihat untuk pertama kali bangkitnya jurnalisme berbasis pasar yang kian berjarak dari pemikiran tanggung jawab terhadap warga."

Kemudian, Kovach dan Rosenstiel (2003:175), menegaskan, "Di zaman media baru, mereka yang memasok kita dengan jurnalisme, wajib paham betul soal pelintiran dan argumentasi dusta yang dikomersialkan, pelobian, dan propaganda politik," sehingga media massa pun bisa dijadikan alat kampanye dan proganda politik paling efektifuntuk melakukan lobi dan tawar-menawar politik kepada publik. Tidak peduli dengan membesar-besarkan fakta, bahkan membuat fakta sendiri, kemudian memelintirnya untuk kepentingan politik. Di sini pun para pelaku politik dapat dengan mudah bekerjasama dengan media massa, tentunya dengan perjanjian komersial.

\section{a. Aspek Berita}

Sikap Kompas sangat mendukung Megawati jadi presiden, sekalipun tidak mengurangi rasa hormat dan keberpihakannya kepada Gus Dur, yang membuat Kompas terkesan mendua, yakni faktor hidupnya strategi politik bisnis Kompas yang selalu mengedepankan nasionalis sekuler.

Strategi yang digunakan Kompas untuk mendulang untung besar dijalankan sangat rapi, sehingga sulit menentukan di pihak mana Kompas berada. Kompas sudah berusaha untuk netral terhadap berita. Namun, ada loncatan ideologi dengan mengusung suksesi memanfaatkan moment pasar demi meraup keuntungan besar. Keberpihakan yang profit oriented dengan strategi menjual informasi yang sangat dibutuhkan pasar (pembaca), adalah bagian operasionalisasi dan tujuan usahanya.

Di sini, Kompas mempraktikkan pemanfaatan jurnalisme pasar, untuk sebesar mungkin meraih keuntungan. Kovach dan Rosenstiel (2003:31) dalam bukunya Sembilan Elemen Jurnalisme, mengatakan:

"Jurnalisme pasar adalah konglomerasi. Para kritikus sudah lama menentang munculnya perusahaan-perusahaan media yang punya jaringan surat kabar atau media elektronik di daerah-daerah atau komunitas-komunitas yang berbeda. A.J. Liebling, kritikus terkemuka pertama terhadap media Amerika Serikat, mengeluhkan gejala konglomerasi ini di halaman-halaman majalah The New Yorker pada tahun 1940-an. Kita sebelumnya sudah menyaksikan munculnya perusahaanperusahaan yang memiliki berbagai media yang berbeda."

Adapun berita-berita Republika edisi Juni dan Juli tahun 2001, menunjukkan keberpihakan tersurat pada terselenggaranya SI MPR, dan itu wajar, karena Gus Dur termasuk yang memperbolehkan perempuan jadi pemimpin. Sekalipun pada awalnya Republika termasuk yang mempermsalahkan wanita jadi Presiden, namun akhirnya mendukung Megawati jadi Presiden, melalui Sidang Istimewa MPR.

Pertimbangan yang dijadikan rujukan bertindak Republika, yakni melihat dan mencermati suhu dan suasana politik dalam negeri yang sudah kalang-kabut. Maka, jika dalam suasana kalut, menurut Republika, Gus Dur tetap dipertahankan, diprediksi akan terjadi kudeta berdarah di bumi Indonesia. Indikasi ke arah itu tampak dari gerahnya kalangan militer terhadap sikap dan perilaku Gus Dur. Pernyataan-pernyataannya yang sering mengambinghitamkan militer, membuat militer diam-diam berbalik memusuhi Gus Dur, walau dalam koridor musuh dalam selimut. Maka, untuk 
menyelamatkan keutuhan bangsa dan negara, daripada militer lagi yang berkuasa, lebih baik Megawati yang memimpin Indonesia.

Walau begitu, sikap Republika yang demikian dipandang surat kabar cenderung emosional dan cepat patah hati (pesimis), dan mudah termakan isu, yang mungkin saja dihembuskan oleh pihak yang berkepentingan untuk menakut-nakuti mayoritas Islam. Berlandaskan hal tersebut, walaupun gaya bahasa yang digunakan cukup keras dan tegas, tetapi netralitasnya diragukan. Kenapa? Karena menurut Alex Sobur (dalam Johan: 2003:87), bahwa kalau berita berdasarkan prasangka dan ketidak-sukaan terhadap seseorang, jangan harap ada netralitas dan validitas nilai beritanya.

\section{b. Penempatan Berita di Surat Kabar}

Di halaman muka (headline), Kompas hanya memuat berita besar sebagai pengantarnya saja. Akan tetapi memberikan pengaruh besar dalam ingatan atau benak pembaca. Contohnya Judul headline Kompas, "Megawati: SI Satu-Satunya Jalan Atasi Konflik." Judul tersebut dimuat di halaman depan dengan tipografi font Arial, cetak tebal, dan ukurannya 40 point. Kemudian, pada edisi 21 juli 2001, Kompas kembali menurunkan headline, dengan judul "Hari ini SI MPR". Melihat judul yang diangkat dan desain ukuran sangat besar, jelas Kompas bemaksud menyosialisasikan bahwa hari ini SI MPR. Dengan judul dari kutipan pernyataan tokoh berpengaruh, validitas beritanya akan dianggap kuat dan netral.

Kompas sangat profesional dalam mengemas berita-berita mengenai kepemimpinan wanita yang dengan sengaja disimpan di halaman dalam, namun menjadi berita besar, karena dikaji dalam artikel berita, wawancara mendalam atau feature berita di halaman dalam tersebut, sehingga hasilnya dianggap memberikan argumentasi kuat terhadap kebenaran masalah. Bahwa SI MPR akan menyelesaikan nasib bangsa, tentunya jika Megawati pun mulus menjabat presiden RI ke-lima -menurut historis dan konstitusi.

Akan tetapi, sangat disayangkan ketika Republika hanya menyediakan ruang yang sedikit di halaman dalamnya. Sedangkan halaman depan (headline) lebih asyik menjual berita, sambil mencurahkan rasa tidak sukanya terhadap pribadi dan pemikiran Gus Dur. Dengan menampilkan dukungan terhadap pelengseran Gus Dur dari kursi presiden.

Pada akhirnya, Republika lebih memilih konsentrasi menurunkan berita-berita yang bisa memengaruhi publik dan elit politik dalam suksesi SI MPR, sehingga Gus Dur turun dari kursi presiden. Kenapa langkah itu diambil, karena dengan dilengserkannya Gus Dur, keberadaan pengaruh Gus Dur sendiri di masyarakat menjadi lemah. Dan indikasi kudeta bisa dihindarkan, karena kalau Megawati yang naik, otomatis si pemenang pemilu berkuasa, dan kalangan yang akan melakukan kudeta, niscaya berpikir ulang untuk melakukan pengambilalihan kekuasaan. Oleh karena, jika Megawati naik, wakil rakyat akan tenang, karena tidak diganggu lagi oleh sang presiden.

\section{c. Kecenderungan Sumber Berita}

Berita yang disajikan suatu media mengenai fenomena yang berkembang di masyarakat, baik masalah politik, agama, budaya, ekonomi, dan lainnya, tentu memberikan daya tawar tersendiri bagi pembacanya. Hal tersebut tidak terlepas dari suatu informasi yang diperoleh wartawan dari pernyataan tokoh, pakar, dan sumber lainnya. Berita yang berisi pernyataan tersebut, tentu saja membawa suatu kepentingan, baik bagi sumber itu sendiri maupun bagi media tersebut, sehingga mengakibatkan terjadinya kecenderungan sikap sumber berita dalam menyampaikan sesuatu mengenai fenomena yang terjadi.

Dalam pandangan Islam, aspek kredibilitas (keterpercayaan, keahlian, kecerdasan, ketokohan) dan keterkenalan menjadi prasyarat yang sangat dijunjung tinggi (Johan, 2003 : 95). Ada satu ayat dalam Al-Quran surat An-Nahl: 43, yang artinya, "Maka bertanyalah kamu kepada orang yang mempunyai pengetahuan jika kamu tidak mengetahui." Hal itu berarti, jika wartawan menginginkan suatu informasi yang kemudian dijadikan bahan berita, hendaklah memikirkan 
Terakreditasi Dirjen Dikti SK No. 56/DIKTI/Kep/2005

terlebih dahulu siapa yang akan dijadikan narasumber dan patut dipertimbangkan disiplin ilmu dan kapasitasnya sebagai sumber informasi. Penjelasan mengenai aspek-aspek, untuk kepatutan sumber atau narasumber berita/hadis/ kabar termaktub dalam ilmu ulumul hadis, bab ilmu jarih wa ta'dil (ilmu hadis yang mempelajari proses pencacatan dan penguatan terhadap suatu berita/ kabar). Aspek-aspeknya meliputi; kecerdasan (dhobit), kepercayaan (amanah), terkenal (masyhuriyah), pujian perihal keahliannya (tazkiyah). Aspek-aspek tersebut sejalan dengan etika komunikasi massa atau dalam kode etik jurnalistik.

Namun, sangat disayangkan dalam praktik jurnalistik, masih ada wartawan yang menanyakan persoalan kepada orang yang kurang atau bahkan tidak memahami masalahnya. Akibat kesalahan wartawan dalam pemilihan sumber informasi, sedikitnya akan mengurangi derajat kepercayaan terhadap kebenaran suatu informasi tersebut (Alex Sobur dalam Johan, 2003: 96). Kalau sumber berita yang diputuskan oleh Republika dan Kompas, dinilai kredibilitasnya apalagi si wartawannya salah sasaran, kebenaran beritanya patut dipertanyakan.

Berdasarkan hasil penelitian yang telah dilakukan dengan menganalisis sumber berita yang mengemukakan suatu pernyataan, dapat dilihat bahwa sumber yang mengemukakan opini dan menjadi berita di harian Republika dan Kompas adalah: tokoh-tokoh Islam, di antaranya: dari PP Muhammadiyah yang memiliki pemikiran moderat, PB NU yang memiliki konsep pemikiran yang cenderung modern, bahkan menjurus liberal, aktivis Islam, pengamat politik, pengamat ekonomi, sosiolog, budayawan, seniman tokoh masyarakat, politisi di kalangan pemerintahan, dan lainnya.

Lebih jelas lagi, ketika Republika edisi 23 Juli 2001 menampilkan pernyataan Amien Rais dalam judul berita, "Insya allah Megawati Jadi Presiden" mengatakan:

"Bahwa para pemimpin parpol sepakat untuk memberikan dukungan pada Ketua Umum DPP PDIP Megawati Soekarnoputri. Kami semua ini sudah bersepakat memberikan dukungan, memberikan moral support kepada Ibu Megawati Soekarnoputri agar nanti dalam pemerintahannya lebih stabil, efektif, produktif, dan memulihkan kepercayaan rakyat yang selama ini sudah hilang dari pemerintah yang ada sekarang."

Munculnya sumber berita Amin Rais memperkuat posisi Republika dalam keberpihakan/mendukung terlaksananya SI MPR dengan anggapan kepemimpinan Megawati dapat menyelesaikan permasalahan bangsa.

Apa yang dilakukan Republika, sejalan dengan pendapat Denis McQuail dalam buku Teori Komunikasi Massa, yang mengemukakan:

\begin{abstract}
"Suatu kenyataan bahwa beberapa orang tertentu dan institusi sebagai sumber berita mendapat lebih banyak perhatian dan keistimewaan. Setiap wartawan masing-masing memiliki sumber yang mereka sukai dan berhubungan dengan para tokoh penting melalui berbagai sarana institusional. Berita seringkali berupa apa yang dikatakan oleh para tokoh penting menyangkut peristiwa tertentu, bukannya laporan tentang peristiwa itu sendiri. Pernyataan para tokoh tersebut dalam kondisi tertentu bahkan bisa dianggap sebaga suatu berita tersendiri, khususnya jika para pembuat pernyataan itu memiliki kekuassan untuk mempengaruhi peristiwa di masa datang." (McQuail, 1987: 163).
\end{abstract}

Kalau benar seperti itu, berarti Republika cenderung lebih memikirkan kepada kesuksesan dalam meraih keuntungan bisnis, dengan harapan jumlah oplah naik drastis, akan tetapi dengan selimut berita seimbangan (netral). Memang kelihatan di muka, kehadiran para narasumber sekilas sudah bisa mewakili permasalahan yang sedang dibahas, namun kredibilitas mereka tersebut patut diragukan dalam berijtihad menetapkan hukum Islam.

Kompas memilih Nurcholish Madjid-Cak Nur- (edisi 26 Juli 2001, "Beri Kesempatan Pada Megawati”), sudah tidak aneh, karena Cak Nur adalah binaan Kompas. Melambungnya nama Cak Nur, tidak terlepas dari peranan publikasi yang saling menguntungkan dari Kompas. Kepekaan Kompas selalu menampilkan Cak Nur 
sebagai narasumber, dianggap sebagai ruh untuk kualitas beritanya. Cak Nur tidak diragukan lagi kredibilitasnya dalam wilayah kajian Islam. Cak Nur merupakan sosok kamus berjalan, gudangnya ilmuilmu Islam. Begitu layak pasar, popularitasnya tidak diragukan lagi. Siapa yang tidak tahu nama Cak Nur. Dengan tampilnya sosok Cak Nur, Kompas merasa jalan kepentingan ideologi atau pun politiknya semakin mudah tercapai.

Kecenderungan para narasumber yang ditampilkan Republika dan Kompas memiliki kemiripan. Bahkan, dalam satu edisi, banyak yang menampilkan sumber berita yang sama dalam angle berita yang sama pula, walau judul dan kemasan berita agak berbeda.

Dari semua ungkapan yang dikeluarkan sumber dalam media di atas, media massa (Republika dan Kompas) mengambil kesempatan dalam menuai pasar, karena popularitas yang dimiliki narasumber berita, ternyata sangat menjanjikan meningkatnya pendapatan perusahaan. Opini yang dimunculkan dapat menarik minat masyarakat dalam mengonsumsi Republika dan Kompas, ditambah para tokoh yang berbicara memiliki massa tersendiri yang secara tidak langsung ingin mengetahui ungkapan dari tokoh yang difigurkannya.

Maka, pihak manajemen perusahaan surat kabar (Republika dan Kompas) memandang momentum ini sebagai kesempatan untuk memunculkan sifat kapitalisme yang mengejar target ekonomi. Di mana kapitalisme sudah menjadikan saluran jasa informasi, menjadi komoditas bisnis yang sangat menjanjikan akan menuai keuntungan besar. Apalagi ditunjang dengan sistem kepemilikan penerbit atau media massa oleh konglomerat, bisa-bisa jurnalisme dikendalikan oleh kepentingan pemilik penerbit atau media massanya. Dalam buku Sembilan Elemen Jurnalisme, dikatakan, "Ihwal penerbit modern yang menyokong kapitalisme tanpa demokrasi tak punya preseden yang berarti dalam sejarah jurnalisme Amerika. Namun kini ada daftar panjang tentang bagaimana kepemilikan media ternyata menomorduakan jurnalisme di bawah kepentingan komersial mereka (Kovach \&
Rosenstiel, 2003: 29).

\section{d. Kecenderungan Berita}

Keputusan Republika, menampilkan lebih banyak berita-berita yang cenderung berpihak kepada terselenggaranya SI MPR dan Megawati sebagai presiden, akan mengundang berbagai pertanyaan, khususnya bagi kalangan umat Islam. Di antaranya, kenapa lebih banyak berita yang berpihak kepada kepemimpinan Megawati. Kemudian, kenapa Kompas lebih banyak menampilkan berita yang cenderung memihak kepada SI MPR dan Megawati sebagai presiden. Hal tersebut sudah jelas sesuai dengan kepentingan yang dibawa media ini sebagai media kelompok nasionalis. Begitu pun dengan Kompas, selain ruang surat kabarnya lebih banyak, juga Kompas sudah banyak yang menyebut sebagai surat kabar nasionalis-sekuler.

Lalu, di mana letak perbedaannya. Republika tampak, walaupun lebih banyak menampilkan berita-berita mendukung SI MPR, belum tentu sepenuh hati menerima Megawati sebagai presiden. Bisa saja karena situasi politik yang dengan terpaksa harus demikian, untuk menyelamatkan negara, atau karena malu atas kegagalan Gus Dur, yang notabene didukung oleh umat Islam (melalui poros tengah). Ini bisa dilihat, berita-beritanya masih menuliskan beberapa pertanyaan atas kesiapan Megawati sendiri.

Bagaimana dengan Kompas? Jangan heran dengan bertebarannya berita-berita yang berpihak kepada Megawati, oleh karena selama ini Kompas sudah memiliki brand image penyalur aspirasi kaum nasionalis, dan kebetulan Megawati dari partai nasionalis, sehingga Kompas pun bersemangat untuk ikut serta berjuang merebut kekuasaan. Adapun jika bahasa atau kemasan beritanya terkesan lunak dan bijaksana, itulah kelebihan Kompas.

Akhirnya, Kompas menuai keuntungan dari berbagai sisi yang memang menjadi target kepentingannya, yakni kepuasan politik kepentingannya dan teologi yang memakai menjadi misi utamanya serta membludaknya pembaca baru yang diprediksi menciptakan keuntungan besar dari 
Terakreditasi Dirjen Dikti SK No. 56/DIKTI/Kep/2005

aspek kepentingan bisnis.

Sikap Republika menjauhi kepentingan Islam mulai memperlihatkan wujudnya. Berita berjudul, "Megawati: Tak Ada Jalan Selain SI (Edisi 19 Juli 2001"), seakan memberikan dukungan mutlak kepada kubu nasionalis - Megawati dan temantemannya-untuk terus maju menyukseskan terselenggarakan SI MPR. Penulis yakin, Megawati sangat senang karena merasa konstituen Islamyang diwakili Republika sebagai suara media massa Islam-telah mendukung dan memperbolehkan wanita menjadi presiden.

Sikap yang ditampilkan Republika, bisa terjadi karena rasa emosional pribadi kepada Gus Dur yang berusaha menghadang suksesi politik Islamnya-yang pendapat menolak presiden wanita, sangat membingungkan konstituen Republika dan Republika sendiri-Atau, oleh karena sudah dirundung rasa pesimistis, karena melihat realitas politik yang terjadi tidak memungkinkan lagi menggolkan kepentingan ideologi politik Islamnya, dengan mencegah Megawati menjadi presiden. Atau, karena situasi politik yang tidak menentu, dan ketakutan terhadap situasi tersebut untuk terjadinya kudeta berdarah. Namun bagaimanapun, pada akhirnya, secara tidak sadar dengan bukti pemikiran dan kebijakannya, Republika tidak lagi bersandar kepada nilai-nilai jurnalistik

Yang terakhir, sampai di mana aspek netralitas berita-berita yang diturunkan Kompas dan Republika dalam memberikan informasi kepada pembaca perihal masalah presiden wanita di detikdetik terakhir terselenggaranya SI MPR dan pelengseran Gus Dur dari kursi Presiden. Hemat penulis, yang terlihat adalah asas pemanfaatan perisiswa aktual-faktual-ideologis tersebut hanya dijadikan komoditas bisnis berita atau informasi dalam mengeruk keuntungan. Adapun kalau ada kepentingan yang dicapai, itu hanya efek samping dari sikap dua muka yang memang sengaja ditampilkan. Muka netral tidak terjadi, yang terjadi adalah muka kepentingan politik sesaat, serta tidak bisa dipungkiri sisi kapitalisme yang hanya memikirkan profit.

Menurut Yusuf Hamdan dalam tesisnya yang berjudul "Gejala Pemihakan Surat Kabar terhadap
Organisasi Politik, mengemukakan:

"Faktor penyebab keberpihakan sebuah surat kabar bisa berbeda-beda. Bisa karena alasan historis, bisnis, rangkap jabatan di organisasi politik dan surat kabar, bisa juga karena sebab-sebab lain. Kecenderungan berpihak surat kabar terhadap organisasi politik tertentu relatif menetap. Tetapi perubahan-perubahan faktor eksternal maupun internal pada tubuh surat kabar yang bersangkutan dapat saja mengubah orientasi isi surat kabarnya." (Hamdan, $1995: 23$ )

\section{e. Aspek Artikel atau Opini}

Dimuatnya artikel atau kolom atau wawancara yang bertema masalah kepemimpinan wanita, boleh-tidaknya wanita menjadi presiden (dalam pandangan Islam), atau legal-tidaknya SI MPR dilaksanakan, oleh Republika maupun Kompas, bukan tanpa alasan. Akan tetapi, dimuatnya artikel atau kolom atau wawancara tersebut, salah satunya, untuk mengukur sejauh mana pandangan pendapat umum terhadap fenomena yang sedang hangat menjadi pokok perhatian ruang publik (Hennessy, 1989:31). Harapan Republika maupun Kompas adalah sama, yakni untuk mengetahui berapa tiras eksemplar yang harus dicetak pada edisi berikutnya. Atau, untuk mengetahui sejauhmana dan sudah sampai di mana, kepentingan redaksi sampai di masyarakat.

\section{f. Kecenderungan Memuat Artikel}

Menurut hemat penulis, terdapat beberapa pertimbangan dimuat tidaknya sebuah artikel di surat kabar. Yang pertama, tema artikel memiliki nilai ilmiah kuat-normatif, empiris dan sistematisKedua, artikel bersifat aktual-sedang hangat diperbincangkan-Ketiga, Artikel tersebut harus memperkuat kepentingan opini publik yang diharapkan redaksi. Adapun mengenai tata bahasa dan gaya bahasa tulisan, sekarang ini bukan menjadi pertimbangan utama, karena redaksi bisa memperbaikinya (fungsi editing).

Edisi 24 Juli 2001, melalui pinjaman tangan artikel yang berjudul, "Akhir Presiden Wahid", yang ditulis oleh Fahri Hamzah, mantan Ketua Umum Komite Aksi Mahasiswa Muslim Indonesia (KAMMI), Republika sudah berketetapan hati 
untuk mengucapkan selamat atas dilengserkannya Gus Dur, serta ucapan selamat bekerja kepada Megawati, yang sudah dilantik sebagai Presiden RI kelima-menurut konstitusi. Maka, berakhirlah masa perjuangan Republika dalam upaya menyisihkan kaum Islam-Liberal yang lebih suka memihak kepada kepentingan demokrasinasionalis-sekuler.

Berbeda dengan Kompas yang sudah jelas dari awal mendukung kepemimpinan Megawati karena Kompas merupakan koran nasioanalis. Kompas segera menampilkan artikel-artikel manamana saja yang, menurutnya, bisa dipinjam tangan-akan berpihak dan memuluskan jalan terhadap kepentingan redaksi-bisa juga stockholder nya.

Sebagai contoh, harian Kompas di edisi 17 Juli 2001 menampilkan judul artikel "Megawati dan Soal Persiapan Jadi Presiden" Rizal Malarangeng, Ph.D, peneliti CSIS, Jakarta. Dalam artikel tersebut, ia mengemukakan peluang Megawati untuk menjadi presiden sudah mendekati absolut (kemutlakan), oleh karena itu, Megawati bersama kubunya (PDIP, nasionalis) tengah bersiap diri untuk mengambil langkah-langkah genius untuk Indonesia masa depan, minimalnya mengamankan Indonesia sampai 2004.

Sindiran-sindiran halus Kompas melalui pinjaman artikel, ternyata pengaruhnya dahsyat, sangat transparan para wakil rakyat memakai rujukan kritikan artikel Kompas tersebut. Kali ini, wakil rakyat mengakui bahwa begitu besar kekuatan realitas politik, yang di pimpin Megawati dan PDIP. Dalam artikel Kompas edisi 24 Juli 2001, yang berjudul, "Kesepakatan Buat Presiden Baru" mengakhiri perjuangan nasionalisme Gus Dur. Megawati benar-benar terpilih menggantikan Gus Dur, yang diturunkan paksa walaupun Gus Dur tidak hadir sehingga tidak menyampaikan pertanggungjawaban presiden. Sindiran artikel Kompas mengenai etika Gus Dur, tepat pula. Mana mungkin presiden tidak melaporkan pertanggungjawabannya. Soekarno saja, pada SI MPR 1967, masih hadir menyampaikan pertanggungjawaban dengan judul yang sangat terkenal "Nawaksara".
Dengan tanpa memperlihatkan perbedaan sejarah lahirnya Republika maupun Kompas, dalam menyikapi fakta politik yang terjadi, mengenai presiden wanita dan SI MPR, kedua surat kabar nasional tersebut lebih memilih duduk di antara realitas kekuatan politik yang ada. Walaupun sangat dimungkinkan di antara keduanya ada perbedaan tujuan. Republika memuat artikel atau kolom yang lebih memihak dan mendukung SI MPR, karena situasi politik tidak dimungkinkan lagi mempertahankan Gus Dur yang sudah gagal total memimpin negara. Kalau Gus Dur tetap dipertahankan, ditakutkan terjadinya kudeta politik, untuk mengambil alih secara paksa kekuasaan, sehingga kontroversi presiden wanita yang tengah kencang-kencangnya diperdebatkan oleh kalangan Islam sendiri, perlu diabaikan dan penyelamatan negara lebih diutamakan.

\section{g. Penulis Artikel atau Opini}

Penulis artikel dan kolumnis yang dimuat tulisannya, bukan tanpa pertimbangan. Selain ukuran ketokohan, keilmuan, dan keahlianya, dan ada satu lagi yang menjadi posisi kritis jika Republika atau Kompas lalai dalam penilaian ukuran ini bisa berakibat fatal -segi bisnis, yakni unsur layak jual. Apakah penulis artikel atau kolom tersebut populer, memiliki pengaruh kuat dan atau berapa jumlah pengikutnya. Alasannya, karena orang-orang tersebut, merupakan opinion leader -pemuka opini, yang berfungsi sebagai pemuka pendapat, klaim, dan sebagainya- bagi masyarakat, tempat bertanya dan referensi ketidaksetujuan atau setuju, tidak sepakat-sepakat, dukung-tidak mendukung, dan sebagainya.

Dalam memilih siapa-siapa saja yang artikelnya akan tampilkan Republika sangat selektif. Namun saying, selektivitasnya hanya berdasarkan pertimbangan kepentingan politik sesaat. Tujuannya, hanya bagaimana artikel yang dimuat tersebut bisa memberikan pengaruh kepada kepentingan politik, yakni memilih artikel atau kolom yang bakal melemahkan kekuatan atau kredibilitas Gus Dur dalam strategi pembunuhan karakter. Artikel atau kolom, sering memperhatikan siapa yang menulisnya, apakah mendukung SI 
Terakreditasi Dirjen Dikti SK No. 56/DIKTI/Kep/2005

MPR atau tidak. Redaksi Republika juga sangat memperhatikan dan meneliti penulis artikel atau kolom, apakah diprediksi memihak dan mengerti kepentingan redaksi. Atau mungkin saja redaksi Republika, menyeleksi dari banyak kiriman tulisan, mana yang sekiranya bakal memperkuat posisi bergaining Republika dalam menyalurkan opini publik mengenai dukungan terselenggaranya SI MPR.

Republika begitu selektif dalam pemilahan penulis artikel atau kolom yang mengisyaratkan dan diprediksi akan mendukung pelengseran Gus Dur dari kursi presiden melalui suksesi SI MPR dan Megawati terpaksa disetujui sebagai penggantinya. Hal tersebut bisa dilakukan dengan mengkaji latar belakang, aspek ketokohan, keterpercayaan, popularitas, pengaruh, kekuasaan, dan layak jual dari para penulis artikel atau kolom yang dimuat Republika.

Dan sebagai bukti, Republika menjalankan strategi politik kepentingan SI MPR, bisa dilihat pada edisi Republika, 24 Juli 2001, melalui pinjaman tangan artikel Fahri Hamzah, mantan Ketua Umum Komite Aksi Mahasiswa Muslim Indonesia (KAMMI), yang berjudul, "Akhir Presiden Wahid". Jelas, dengan hadirnya tokoh muda Islam yang moderat diakhir konflik, Republika lebih senang menghadirkan kalangan Islam Moderat yang memiliki pandangan pemikiran politik Islamnya tidak secara parsial. Kalangan Islam Moderat sangat memerhatikan situasi politik (realitas yang terjadi), kalau memang demi kemaslahatan umat dan menyelamatkan Indonesia, hadirnya presiden wanita diperbolehkan karena faktor kemudaratan demi mencapai kemaslahatan umat.

Berdasarkan hasil pengamatan yang telah dilakukan dengan menganalisis sumber berita yang mengemukakan suatu artikel atau opini, bisa dikatakan bahwa sumber yang mengemukakan opini di Harian Republika lebih dominan kalangan Islam Politik, yang lebih memihak pada kiblat politik gaya Amerika Serikat, yang menganut ajaran demokrasi liberal. Seharusnya, untuk menjaga keseimbangan opini dan informasi, alangkah tepatnya Republika juga menghadirkan intelektual
Islam yang notabene menolak presiden wanita, karena mungkin saja yang berpendapat demikian lebih banyak dari kalangan Islam moderat, yang karena alasan kemaslahatan umat dan untuk menyelamatkan negara, presiden wanita tidak dipermasalahkan lagi.

Sedangkan Kompas yang dari awal jelas berpihak kepada Megawati, walaupun terkesan malu-malu kucing, menampilkan penulis artikel atau kolom, yang menurut Kompas bakal berpihak dan memuluskan jalan terhadap kepentingan redaksibisa juga stockholdernya-tanpa melihat kredibilitas penulisnya sendiri terhadap masalah kepemimpinan wanita menurut Islam (yang masih saling ngotot memperdebatkannya) yang berakibat pada ijtihad hukum.

Bisa dilihat pada edisi 17 Juli 2001, Kompas menampilkan Rizal Malarangeng, Ph.D, peneliti CSIS, Jakarta, yang menulis artikel, "Megawati dan Soal Persiapan Jadi Presiden". Tampilnya Rizal Malarangeng yang notabene ahli politik dan kredibilitas intelektualnya tidak diragukan lagi oleh masyarakat, akan membawa dampak semakin menguatnya kepercayaan masyarakat untuk menyakinkan dan menerima Megawati sebagai presiden wanita pertama RI, melalui SI MPR.

Jika dikaji, ternyata Kompas menggunakan strategi "pemanfaatan kredibilitas dan popularitas serta ketokohan" dan mengenyampingkan dampak negatif terhadap nilai penjualan tiras surat kabarnya. Namun, Kompas sangat diuntungkan, karena penulis artikel (popularitas dan kredibilitas Rizal Mararangeng) tersebut bisa memperkuat penggiringan publik dalam memberikan dukungan terselenggaranya SI MPR, sehingga suksesi Megawati sebagai Presiden, berjalan lancar.

\section{h. Aspek Tajuk Rencana}

Tajuk rencana merupakan sikap redaksi mengenai fenomena yang berkembang di masyarakat. Hal tersebut, tentu saja, membawa kepentingan media tersebut di mata pembaca.

Dalam tajuk rencana, akan timbul pertanyaan perihal pendapat siapakah yang dibawa oleh tajuk rencana? Untuk menjawab pertanyaan tersebut, Ja'far Assegaff(1991: 64), dalam bukunya berjudul 
Jurnalistik Masa Kini, Pengantar Praktek Kewartawanan, menjelaskan:

"Jelas sekali tajuk rencana membawakan pendapat surat kabar dan dukungan modal atau organisasi yang ada dibelakang surat kabar itu. Penulis tajuk rencana, yang umumnya adalah pemimpin redaksi atau redaktur senior haruslah merupakan orang yang terpercaya dan mengetahui kebijakan pemberitaan maupun kebijakan surat kabar di mana ia bekerja. Sebagai contoh, harian Suara Karya tentunya membawakan pendapat pemikiran golongan Karya (baca : kini Partai Golkar), Harian Pelita tentunya membawakan pendapat PPP (Partai Persatuan Pembangunan). Surat-surat kabar seperti Kompas dan Sinar Harapan yang sering menyebut dirinya surat kabar independen, sering dikatakan orang pembawa pendapat golongan Katolik dan Protestan, karena modal dan pimpinannyaberada pada tangan-tangan orangorang terpercaya dari kalangan tadi. Pada suratsurat kabar lainnya yang menyebut dirinya independen, sering nampak kecenderungan sikapsikap, moderat, liberal, dan konservatif.

\section{i. $\quad$ Kecenderungan Sikap Redaksi Menyajikan Tajuk Rencana}

Di tajuk rencana Republika maupun Kompas, publik akan bisa mengetahui, ke arah mana sikap politik Republika maupun Kompas, menyalurkan aspirasi politik, agama, budaya atau yang lainnya. Dengan tajuk rencana pula, sikap dan kepentingan para pemodal atau organisasi (sosial, politik, agama, budaya, atau seni) yang berada di belakang Republika maupun Kompas, akan tersalurkan dan terakomodasi dengan baik. Untuk mengkaji kecenderungan tajuk rencana Republika, dalam kondisi politik serta penyikapannya dapat terlihat, seperti contoh-contoh tajuk rencana di bawah ini.

Pada edisi 16 Juli 2001, Republika mengeluarkan tajuk rencana berjudul, "PDIP Mempertegas Sikap “. Isi dari tajuk tersebut, mengetengahkan perihal sikap PDIP yang sudah tegas dan bulat untuk mempercepat SI MPR, demi keutuhan negara dan demi menyelamatkan negara. Percepatan mutlak dilakukan, jika situasi dan kondisi negara semakin memburuk, sebagai akibat dari tindakan dan perilaku presiden. Di akhir tajuknya, Republika menegaskan dukungannya kepada Megawati, sebagai yang akan menggantikan Gus Dur. Sikap tersebut dilakukan oleh Republika, sebagai konsekuensi konstitusi jika pertanggungjawaban Gus Dur ditolak MPR.

Mengapa Republika bersikap demikian? Perlu diketahui bahwa situasi politik pada saat itu, sudah memperlihatkan tanda-tanda krusial, ditakutkan negara akan mengalami kondisi paling terburuk. Ini terlihat dari banyakanya informasi dan selentingan, mulai ancaman disintegrasi, dekrit presiden, dan kekacauan-kekacauan lainnya, sehingga bisa dijadikan alasan pihak militer untuk mengambil alih kekuasaan secara paksa. Untuk itu, jauh-jauh hari Republika tidak malu-malu lagi dianggap mengkhianati kepentingan Islam. Karena mungkin setelah mengkaji dan menganalisis informasi tersebut, Republika lebih menomorsatukan kepentingan penyelamatan bangsa dan negara, dan itu merupakan paling utama yang segera dilakukan. Jalan keluar dari situasi tersebut, jelas, yakni segera terselengaranya SI MPR yang konstitusional, yang akan meminta pertanggungjawaban Presiden Gus Dur.

Di tajuk rencana Kompas edisi 23 Juli 2001, "Kedaulatan Adalah di Tangan Rakyat dan Dilakukan Sepenuhnya Oleh MPR," merupakan sikap dukungan Kompas untuk para wakil rakyat untuk segera SI MPR, karena menurut konstitusi kedaulatan ada di tangan rakyat. Itu betul, akan tetapi pelaksanaan kedaulatannya dilakukan sepenuhnya oleh MPR. Tajuk ini dikeluarkan untuk memberikan tanggapan atas terbitnya Dekrit Presiden, yang secara konstitusi ilegal. Dan benar saja, keluarnya dekrit, direaksi oleh MPR dengan dipercepatnya SI-MPR. Pada 23 Juli 2001 pula Gus Dur tetap tidak bersedia hadir untuk membacakan laporan pertanggungjawabannya, sehingga otomatis SI MPR melengserkannya. Tidak lama setelah itu, MPR mengangkat Megawati sebagai presiden RI ke-5.

Tajuk-tajuk rencana Kompas, dibalut dengan tata dan gaya bahasa sastra yang halus dan kiasan, akan tetapi memberikan sindiran keras memihak/ mendukung kepada Megawati dan melemahkan 
Terakreditasi Dirjen Dikti SK No. 56/DIKTI/Kep/2005

secara kredibilitas (praktik pembunuhan karakter) Gus Dur secara halus, sehingga di muka kelihatan mendukung Gus Dur, netral, akan tetapi jika ditelaah lebih mendalam, justru lebih pedas dari surat kabar lainnya. Mengapa demikian? Selain untuk memelihara julukan surat kabar paling cerdas, netral, profesional, juga demi menyelamatkan muka Kompas yang sering dibantu oleh Gus Dur, dalam kepentingan ideologinya.

Namun, walaupun pun tajuk rencana merupakan wilayah kekuasaan redaksi surat kabar (seperti Kompas) untuk memainkan opini secara bebas ke arah kepentingan yang disukainya, tetap harus memerhatikan fakta-fakta dan berpegang kepada kejujuran untuk mengungkapkan kebenaran. Kovach dan Rosenstiel (2003: 175) dalam buku Sembilan Elemen Jurnalisme, mengatakan:

"Halaman editorial surat kabar, kolumnis opini, acara bincang-bincang, dan esai majalah yang menyikapi sebuah masalah memang punya hak untuk beropini. Namun, jika penulisnya ingin menyebut diri wartawan, mereka tak boleh salah menyajikan fakta-mereka harus berpegang pada standar kejujuran yang sama atau kesetiaan pada kepentingan publik sebagaimana bagian lain profesi ini."

\section{Penutup}

Dengan memperhatikan hasil pembahasan setiap aspek isi surat kabar yang dianalisis (meliputi frekuensi, volume, aspek berita, artikel, dan tajuk rencana), maka dapat disimpulkan bahwa pada surat kabar Republika maupun Kompas terdapat indikasi yang nyata untuk memberikan persepsi, menyatakan sikap tentang isu kemungkinan Megawati menjadi Presiden di tengah kontroversi kepemimpinan wanita menurut konsepsi Islam. Kedua surat kabar tersebut menyatakan dukungannya (keberpihakannya) terhadap kepemimpinan wanita selama dua bulan edisi (Juni sampai dengan Juli 2001).

Republika pada mula pemberitaannya di bulan Juni menampilkan suatu sikap dan menyajikan pemberitaan yang menolak kepemimpinan wanita dengan melihat indikasi kemungkinan Megawati menjadi presiden. Namun, dari pertengahan bulan Juni, Republika mulai memperlihatkan sikap yang memihak kepada Megawati. Dilihat dari pemberitaannya, baik dari segi berita, artikel, maupun tajuk rencananya, cenderung memihak dan sekaligus menyeujui kepemimpinan wanita. Hal tersebut dilakukan dengan melihat realitas yang terjadi di masyarakat serta permintaan untuk mendapatkan keuntungan dari segi bisnis dan politik, tetapi sangat disayangkan karena kepentingan ideologi (teologi) menjadi hal yang tidak diprioritaskan kembali sebagai misi dakwah.

Berbeda halnya dengan Kompas, pada pemberitaannya sejak awal Juni sudah mempelihatkan sikap yang berpihak kepada Megawati menjadi presiden atau kepemimpinan wanita, sehingga ada tiga keuntungan yang diperoleh, yaitu keuntungan bisnis, politik, dan teologi (ideologi agama).

Jika dihubungkan dengan pertanyaan pokok masalah dalam tulisan ini, "Sejauhmana perspektif media massa terhadap presiden wanita di Indonesia", maka dapat dinyatakan bahwa berdasarkan pada indikasi-indikasi yang tampak pada berbagai unsur yang diteliti, kedua surat kabar tersebut memperlihatkan sikap yang mendukung kepemimpinan wanita. Hal tersebut diperoleh berdasarkan frekuensi yang banyak, volume atau ruang yang disediakan cukup besar pada setiap edisi, serta kecenderungan yang mayoritas mendukung kepemimpinan wanita, baik dari segi berita, artikel, maupun tajuk rencana.

Perspektif media dalam menyikapi permasalahan kepemimpinan wanita ditunjukkan melalui berita, artikel, dan tajuk rencana yang disajikan pada kedua surat kabar tersebut, dengan banyaknya frekuensi serta besarnya volume atau ruang yang disediakan, narasumber dan sumber berita, serta banyaknya unsur sikap yang mencerminkan kecenderungan atau pemihakan. Dalam hal ini, kedua surat kabar tersebut ternyata memberikan ruang yang cukup besar dan frekuensi yang banyak untuk menyajikan pemberitaan kemungkinan kepemimpinan wanita menjadi presiden di Indonesia yang mayoritas penduduknya adalah Muslim. Begitu pula dengan 
kecenderungan baik dari segi berita, sumber berita, artikel, narasumber, maupun sikap redaksi, ternyata menyatakan dukungan terhadap kepemimpinan wanita.

Dikaitkan dengan model agenda setting surat kabar yang dikemukakan pada kerangka pemikiran, maka kedua surat kabar (Republika dan Kompas) memperlihatkan kecenderungan bahwa mereka menjalankan fungsi agenda setting yang disesuaikan dengan isu yang politik yang sedang berkembang dan menghangat. Di mana permasalahan yang terjadi diteliti oleh stimulus, meliputi sifat dan keinginan khalayak. Kemudian, hasil stimuli terhadap sifat dan keinginan khalayak, dijadikan prioritas dalam setiap pemberitaannya. Pemberitaan tersebut merupakan persepsi dan aksi dari kedua surat kabar (Republika dan Kompas) tersebut terhadap isu yang sedang terjadi dan aktual, sehingga isi surat kabarnya memiliki kecenderungan untuk memihak kepada Megawati menjadi Presiden RI, Pasca Memorandum II dan SI MPR.

Alasan kecenderungan memihak dapat berupa kepentingan bisnis, politik, teologis (khususnya bagi Kompas), serta faktor lainnya.

Kecenderungan berpihak surat kabar terhadap isu kepemimpinan wanita tidak selalu dapat terlihat secara serta merta dengan mengamati isi surat kabar secara sekilas, melainkan harus dengan pengamatan untuk periode tertentu dan mencakup hampir seluruh isi surat kabar yang dianggap penting untuk maksud penelitian.

Pada akhirnya, sulit untuk sangkal lagi bahwa perspektif media kedua surat kabar tersebut lebih memilih alasan isu dan kontelasi politik yang sedang gonjang-ganjing dan alasan demi kuutuhan negara, aspek jurnalisme diabaikan begitu saja. Yang terpenting bagi kedua surat kabar tersebut (Republika dan Kompas), Gus Dur turun dan Megawati naik menjadi presiden. Untuk target bisnis, kedua surat kabar tersebut memiliki kepercayaan, karena yang dijual adalah informasi/ berita hangat, sensasional dan sensitif terhadap nasib hidup masyarakat, dipastikan meraup keuntungan besar.

\section{Daftar Pustaka}

Alfian. 1993. Komunikasi Politik dan Sitem Politik Indonesia. Jakarta: Gramedia.

Arfan, Floyd G. 1970. Wartawan Pembina Masyarakat. Saduran Rochady Bandung: Binacipta.

Assegaff, Dja'far H. 1983. Jurnalistik Masa Kini. Jakarta: Ghalia Indonesia.

Baran, Stanlay J. Dennis K. Davis. 1999 Massa Communication Theory: Foundaions, Ferment, and Future. $2^{\text {nd }}$ ed. Canada: Wadsworth, a division of Thomson Leaning.

Dominick, Joseph R. 1983. The Dynamics of Mass Communication. New York: Newbery Award Records, Inc.

Effendi, Onong Uchyana,.1993. Ilmu, Teori dan Filsafat Komunikasi. Bandung: Citra Aditya Bhakti.

Emmert, Philip \& Larry L.Barker. 1989. Measurement of Communication Behavior. New York \& London: Longman

Eriyanto. 2001. Analisis Wawancara: Pengantar Analisis Teks Media. Pengantar

Dedy N. Hidayat. Cetakan I. Yogyakarta. LkiS.

Garna, K, Judistira. 1993. Ilmu-ilmu Sosial DasarKonsep-Posisi. Bandung: PPs Unpad

Hamdan. Jusuf. 1995. “Gejala Pemihakan Surat Kabar terhadap Organisasi Politik: Analisis Isi Surat Kabar Kompas dan Pikiran Rakyat dalam masa Kampanye Pemilu 1992. Tesis S-2.” Bandung: PPs Unpad

Harimulyana, Agus., Satrio Arismunandar. 1999. Megawati Usaha Taklukan Badai. Jakarta: mBoro Kinasih.

Heryanto, Ariel., dkk. 1996. Bahasa dan Kekuasaan: Wancana di Panggung Orde Baru. Bandung: Mizan. 
Hart, Andrew. 1991. Understanding Media: A Practical Guide, Library of Congress Cataloguing. USA: in Publication-Data.

Hennessy, Bernard. 1981. Pendapat Umum. Edisi ke-4. Ahli bahasa Amiruddin Nasution. Jakarta: Erlangga.

Holsty. 1981. Content Analysis an Introsuction; Reading ini Public Opinion and Mass Communication. New York: The Free Pers Mac Millan Publisihing Co. Ic.

Kamus Besar Bahasa Indonesia. 1995. Edisi Kedua Cetakan keempat. Jakarta: Balai Pustaka

Liliweri, Alo. 1991. Memahami Komunikasi Massa dalam Masyarakat. Bandung: Citra Aditya Bakti.

Mc Quail, Denis. 1987. Teori Komunikasi Massa; Suatu Pengantar. Jakarta: Erlangga.

Mulyana, Deddy. 1999. Nuansa-Nuansa Komunikasi: Meneropong Politik dan Budaya Komunikasi Masyarakat Kontemporer. Bandung: Remaja Rosdakarya.

Nimmo, Dan. 1989. Komunikasi Politik, Terj. Tjun Suryaman. Bandung: Remaja Rosdakarya.

Oetama, Jacob. 1987. Perspektif Pers Indonesia. Jakarta: LP3ES.

Poloma, Margareth,M. 1994. Sosiologi Kontemporer. Jakarta: Raja Grafindo Persada.

Rakhmat, Jalaluddin.1996. Metode Penelitian Komunikasi. Bandung: Remaja Rosdakarya.

Rauf'izzat, Hibah. 1997. Wanita dan Politik Pandangan Islam. Bandung: Remaja Rosdakarya.

Rauf, Maswadi., Mappa Nasrun. 1993. Indonesia dan Komunikasi Politik. Jakarta: Gramedia Pustaka Utama.

Sendjaja, Sasa. 1998. Sistem Media Massa yang Adil dan Demokratis sesuai Tuntutan Reformasi, Jurnal ISKI No.1/Juli 1998, Bandung: Remaja Rosdakarya.

Stempel III, Guido H. Analisis Isi. Terj. Jalaludin Rakhmat dan Argo K.Sukatendel. Bandung: Arai Komunikasi.

Sobur, Alex. 2001. Etika Pers: Profesionalisme dengan Nurani. Bandung: Humaniora Utama Pers.

Strabhaar, Joseph and La Rose, Robert. 2000. Media Now. USA: Wadsworth Publisihing Company A Division of International Thomson Publisihing, Inc.

Susanto, Astrid, S. 1982. Komunikasi Kontemporer. Bandung: Bina Cipta.

Veeger, K.J. 1985. Realitas Sosial. Jakarta: Gramedia.

Tebble, John. 2000. Karier Jurnalistik. Ahli bahasa Dean Praty Rahayuningsih. Semarang: Effhar dan Dahara Prize.

Ward, Ian. 1995. Politics of the Media. Australia: Associated Companies and Representatives Throughout The World.

Wright R. Charles. 1985. Sosiologi Komunikasi Massa. Bandung: Remaja Karya.

Yamani, Mai. 1996. Feminisme dan Islam: Perspektif Hukum dan Sastra. Bandung: Nuansa.

Zulkifli, Arif. 1996. PDI Di Mata Golongan Menengah Indonesia: Studi Komunikasi Politik. Jakarta: Pustaka Utama Grafiti. 
